M.B.Hecnpaвa,

здобувач кафедри філософії ДНУ ім. Олеся Гончара

\title{
ЗА МЕЖАМИ РОЗУМІННЯ ЗЛА У ФІЛОСОФІї ПОСТМОДЕРНУ
}

Мислителі минулого уявляли безконечне в різних формах: як Космос, Логос, Бог, Макрокосм, Всесвіт, як взаємозв'язок людини i Всесвіту, добра і зла. Ці ідеї можливо постежити у працях Платона, Аристотеля та ін.

У дослідженнях вітчизняних науковців Л.Филипович, В.Малахова, С.Кримського, Т. Чайки, Ю. Чорноморця, А. Баумейстера та інших розкривається взаємозв'язок безкінечного та людського способу буття, доводиться наявність морального універсалізму і загальнолюдської сутності, яка реалізується в індивідуумі, коли він має можливість розвиватися в природному для себе культурному середовищі. Стан людини - це завжди боротьба між добром і злом, це історія індивіда та історія спільноти.

Розглянемо межі зла та розуміння філософією постмодерну процесів розвитку цивілізацій, шляхів розвитку людства.

Зло за своїм змістом постає запереченням повноти буття, утвердженням хаосу, множинності та егоїзму, які розгортаються в більш приватні цінності. Питання, що стосуються природи зла, сутності та змісту негативних моральних цінностей завжди були актуальними і складними для тих етичних учень, які виходили з об'єктивної природи добра і при цьому доводили його божественну сутність.

Всемогутній Бог-Творець може допустити творення та існування зла. Адже існування зла пов'язане з проблемами теодицеї, які й $\epsilon$ випробуванням нашої віри та розуму. У християнстві зло пов'язується як 3 гріхопадінням людини, так і з гріхопадінням ангелів. Головною причиною гріха постає в тому і в іншому випадку егоїзм, бажання стати «як боги». Зло, створене Люцифером, або Денницею та іншими ангелами і здійснюване ними над природою, а далі й людьми, істотно змінило якість буття, сповнивши його негативними цінностями [1,303-304].

Становлення зла та гріха має історичний характер. За однією 3 гіпотез, Зло увійшло в світ через гріх. Адже у своїй реальній життедіяльності ніхто з людей не може цілком уникнути зла. Втім можна 
й потрібно уникнути гріха.

Концепції зла можна поділити на два види: моністичні та дуалістичні.

У дуалістичних зло представлено в релігійних та ідеалістичних вченнях, як, наприклад, у зороастризмі, у маніхейців, Платона, Шеллінга, Бердяєва та ін.

3 цієї точки зору, в світі життєдіяльність має два начала: одне (добре, світле) ототожнюють 3 ідеальним Богом, а інше (зло, темне, меонічне) - ототожнюють $з$ матерією. Недоліком цих концепцій $є$ песимізм щодо можливостей добра та перемоги добра над злом.

У моністичних ученнях про природу зла можна виокремити матеріалістичне та ідеалістичне спрямування. У матеріалістичному прикладом може бути марксистська філософія, яка визнає матеріальну першопричину, чинну з природною необхідністю, яка тому позбавлена моральної відповідальності. Але в ній заперечується метафізичне, фізичне і трансцендентне зло, а визнається лише соціальне і моральне. Тому і головними засобами боротьби зі злом визнається процес наслідування соціальних і моральних норм поведінки, вчинків, взірців тощо.

Однак певна утопічність всіх подібних соціально-моральних програм боротьби зі злом, коли й сама моральність розуміється вузько - як суб' єктивний або суб'єктивно-об'єктивний феномен, свідчить про іiі недосконалість. Це визначається обмеженим уявленням про зло.

Значущість соціального та особистісного факторів у протиборстві зі злом доведено в матеріалізмі.

Розуміння зла є проблемою для моністичних релігійних і релігійно-філософських учень, для християнського світогляду. Апостол Павло, Діонісій Ариопагит, Іоанн Лествиничнико та інші святі отці церкви особливу увагу приділяли моральному і трансцендентному злу, яке пов'язано з феноменом віри [3].

Наукові узагальнення щодо взаємозв'язку людини і природи, людини і цивілізації, добра і зла простежуємо у працях Лейбниця, Дж. Локка, Т.Гоббса, Ж.А.Н.Кондорсе, А. де Сен-Сімона, О.Конта. Так Ж.Кондорсе та інші філософи вважали, що технічний прогрес, поширений на всю систему панування людини над природою, пов'язаний з вірою, спрямовану на координацію зусиль цивілізації в силу розуму, який створює нові форми життя (і влади), але обмежує перспективи свободи від надмірної праці та панування $[5,8]$. Завдяки 
цьому сучасне суспільство здатне до соціальних перетворень - кількісних змін, впровадження новацій у виробничу та наукову сфери життя, обгрунтування нових взірців людського існування. Цивілізація перетворює об'єктивний світ у царину панування розуму й тіла людини, ставлячи під сумнів саме поняття відчуження. Люди пізнають себе у своїх товарах: знаходять свою душу в автомобілях, побутовій електроніці, у житлі, в якому регулюються рівні поверхів, у кухонному обладнанні. Змінився механізм, який пов'язує індивіда $з$ суспільством, а соціальний контроль зумовлює нові потреби життєдіяльності.

Сьогодні актуалізується термін «вкладування» («інтроекція»«introjection»), який не описує спосіб, у який індивід сам відтворює й увічнює зовнііїші форми контролю. Інтроекція передбачає різноманітні, спонтанні процеси, за допомогою яких «Я» (Ego) переміщує «зовнішнє» у «внутрішнє». Вона означає існування внутрішнього виміру, що відрізняється від зовнішніх форм граничної необхідності, - індивідуальна свідомість та індивідуальне несвідоме відокремлені від громадської думки й поведінки $[15,96]$. Вплив прогресу приводить Розум до підкорення фактам життя і до здатності виробляти більші й масштабніші факти такого самого способу життя. Дієвість системи притупляє визнання індивідом того, що вона не містить фактів, які б не передавали репресивну силу цілого. Сьогодні індивіди знаходять себе в речах, котрі формують їхнє життя.

Життєвий стандарт найрозвинутіших індустріальних регіонів та країн не становить належної моделі розвитку. Стало зрозуміло, що «суспільство споживання» є суспільством постійної мобілізації проти ризику знищення. Продаж товарів, поширення комфортного існування людини супроводжується поширенням розумової відсталості, виснажливої праці й сприянням фрустрації.

Визнання здобула «Теодицея» Г. Лейбніца («Виправдання бога»). Це -спроба довести, що, незважаючи на безперечну наявність у світі недосконалості та морального зла. Риси недосконалості та явища зла - необхідна умова гармонії світу. Г. Лейбніц визнавав метафізичне зло (недосконалість), фізична (страждання) і моральне (гріх). Він вважав, що Всемогутній і Благий Бог створив досконалий 3 можливих світів. Інший би не відповідав природі Бога, зло має приватний характер, є неодмінним елементом встановлення більш загального добра. Тож зло відносне і є необхідністю. Мовляв, краще, якщо буде грішник, який зазнаватиме за гріхи свої вічну кару, ніж 
світ виявиться менш досконалим, ніж є [7].

У концепціях К.Маркса, М.Я.Данилевського, О.Шпенглера, А.Тойнбі, К. Ясперса описано поступ цивілізації як процес деградації культури, як поступову деградацію добра. Мислителі наголошують, що потрібно визнати реальність зла, яке пов'язане з фізичною недосконалістю, психічним стражданням, за моральними вчинками, 3 соціальним насильством, метафізичними диявольськими спокусами та ін. Предметними субстанціями цих видів зла є певні, так звані негативні властивості, пристрасті. Саме тому Зло визначається як найбільш загальна негативна моральна цінність, представлена через сукупність конкретних цінностей.

Негативна цінність існує сама по собі як певна якість, а саме як специфічна властивість насамперед таких властивостей, як каліцтво, насильство, егоїзм, злість тощо. Ці якості «негативних» якостей не $\epsilon$ просто недоліком добра, а постають за своїм змістом зовсім іншими недосконалими якостями. Саме тому відносне добро - це завжди добро. Наявність тонкої межі між добром і злом свідчить, що цінності добра і зла є антагоністичними властивостями, що існують спочатку в низці дійсностей. Так, наприклад, і страждання, яке іноді помилково ототожнюється зі злом і яке справді пов'язане 3 певними видами «психічного», морального зла, може бути проявом добра. Хрест як символ страждання постає водночас і символом морального життя в певній дійсності, де міститься багато зла.

Моральні норми вважаються легітимними, якщо вони вкорінені у людському житті, а не нав'язуються ззовні. Самі цінності добра і зла трансцендентні. Тому для дереалізації завдань зла потрібне досягнення досконалості, що досягається через сукупність певних якостей.

Зло не може існувати автономно. Воно постає лише запереченням добра, по суті своїй є чимось руйнівним, а не творчим. А.Макінтаєр вважає перехід від звичайного стану до моральної досконалості переходом від просто життя до доброго життя [3, 291-296]. Грецький термін «добра звістка» (Свангеліє) утверджує можливості «доброго життя» в особистій спільноті та в загальнолюдській історії.

Розрив між людиною і Богом має онтологічне підгрунтя. Про це пише М.Лосський у праці «Бог і світове зло»: «Онтологічно (буттєво) Бог постає не лише як Божественне Ніщо, але й як особисте буття Бога-Отця, Сина і Духа Святого, відокремлений від світу глибокою 
прірвою...» $[8,202]$.

Але замість культивування чеснот людина нового часу починає культивувати саму себе, про що вдало пише сучасний філософ Ч.Тейлор [10]. Це культивування себе стає прихованим механізмом, який працює на секуляризацію європейської цивілізації та знищує традиційне релігійне суспільство. Вони доводять, що глобалізація поглиблює відчуження: між країнами з різними релігійними, етнічними та культурними традиціями; між людьми з різним рівнем освіти та різним світоглядом; між різними поколіннями людей, які по-різному сприймають динаміку комунікацій і виховані в різних системах масової культури.

Суперечливості сучасного життя ускладнюють сприйняття світу в межах звичних образів і стереотипів, породжуючи низку фантасмагоричних концепцій. Актуалізуються ідеї постмодернізму, художні образи демонструють різноманіття форм виживання 3 метою подолання відчуження в сучасному суспільстві.

Впливовим явищем сучасності виступає і глобалізація, з якою пов'язані соціально-економічні та філософсько-світоглядні ідеї та мислення. Різні аспекти розуміння зла зафіксовано префіксом «пост», зокрема обмеження волі.

Процеси розвитку цивілізацій та різні шляхи розвитку людства передбачували філософи Ф.Фукуяма, В.Валлерстайн, С.Хантінгтон, П.Дж. Б’юкенен та ін.

Вони також визнають панування зла в капіталістичному суспільстві. Якщо дії зумовлені природною чи соціальною необхідністю, то, навіть спонукаючи суб'єкта до зла, вони не є гріхом, а пов'язане 3 ними зло не є гріховним. Наприклад, бізнесмен різко збільшує ціни на свій товар, оскільки відбулася девальвація грошей. Безсумнівно, що ці дії негативно позначаться на добробуті людей, особливо малозабезпечених. I з цього погляду вони є зло, але не гріх, бо жорстко визначені економічними законами бізнесу.

Відомо, гріх $є$ там, де $\epsilon$ порушено принцип максиміна. Принцип максиміна означає вибір у ситуації альтернативи з альтернатив, найгірший результат якої перевершує гірші результати інших альтернатив. Він схожий з принципом найменшого зла, однак припускає дійсними не тільки гірші результати, але й можливі, що вимагає раціонального змістового осмислення ситуації $[9,140]$.

Сьогодні актуалізуються дослідження особливостей становлення і розвитку інформаційного постіндустріального суспільства. 
К. Болдуінг, Д.Белл, Дж.Гелбрейт, О.Тоффлер, М.Маклюєн та інші зазначають, що реальністю стає віртуальний світ, який сьогодні $\epsilon$ атрибутом повсякденності. Буття сучасної людини - це буття, що відбувається в кількох вимірах, кількох світах, пов'язаних з життям в ілюзіях. Тому інтерес становлять ідеї Р.Снукса, А.Д.Панова, Н.Н.Мойсеєва, А.П.Назаретяна, С.Хантінгтона та ін. Інтелектуалізація техніки, іiі олюднення також криє низку небезпек для людини, трансформацію iii волі. Воля як суб' єктивна здатність до самодетермінації дуже істотна для моральності людини, бо характеризує людську свободу щодо вибору добра або зла. 3 одного боку, етика виходить 3 того положення, що воля людини спочатку відзначається своїм вільним характером від час такого вибору. І в цьому - відмітна особливість людини, особливість, що виокремлює ії з тваринного світу. 3 іншого боку, мораль сприяє розвитку даної здібності, формує так звану позитивну свободу, як здатність вибрати добро, навіть усупереч власним пристрастям або зовнішнього примусу.

У праці «Повстання мас» Хосе Ортега-і-Гассет наприкінці 1920-х років передбачав деградацію суспільної моралі та традиційних цінностей і те, що «повстання машин» може обмежити права і можливості самої людини. Якщо комп'ютери почнуть розподіляти ресурси відповідно до власних потреб, це відбуватиметься не на користь людства.

Складність обчислювальних процесів призведе до створення єдиного штучного інтелекту, впевнені X'ю Прайс і Яан Відень один 3 творців Skype. А критичний момент настане тоді, коли цей «загальний розум» зможе самостійно створювати комп'ютерні програми і розробляти технологію для відтворення подібних до себе.

Феномен віртуальної реальності досліджують такі зарубіжні та українські вчені: А.Алексєєв, О.Бойко, Ф.Власенко, Н.Смєльянова, С.Курбатов, С.Марійко, А.Переломов та ін. Механізмом формування і поширення віртуальної реальності $є$ насамперед мережа Інтернет. Її взаємодія із суспільством становить своєрідну форму буття людини. Інтернет можна трактувати як засіб та середовище існування поза суспільством, якщо суспільство розуміти в традиційному для соціальної теорії значення - як систему соціальних інститутів. Однією з характерних ознак віртуальної реальності є те, що індивід може змінювати власну реальну індивідуальність на вигадану, віртуальну. 3 одного боку, така реальність дає свободу ідентифікації - іншу, вигадану соціальну роль, соціальний статус, 
інше ім'я, звички тощо, а з другого, поряд із цим, - індивід втрачає свою реальну ідентичність, своє «Я».

$€$. Уханов констатує, що відбувається порушення у сприйнятті простору і часу [11]. Іншою особливістю, на його думку, є те, що внутрішні образи, які виникають під впливом віртуальної реальності, постають індивіда як реальні, такі, що об’єктивно існують. Людина сприймає віртуальний світ не як продукт власної психічної діяльності - уяви, а як об'єктивну реальність. Віртуальні об'єкти у віртуальній реальності С. Уханов характеризує через поняття «симулякр» та «симуляція». Суттєвою причиною заглиблення людини у віртуальну реальність є соціальний (реальний) світ, який не надто привабливий своєю жорстокістю та випробуваннями [11].

Людська історія може характеризуватись як пошук «таємничих» онтологічних Батьківщин та реальностей на «відкритому фронті світу» $[2,192]$, практико-пізнавальний процес входження в дійсність, який дозволяє перетворення предметів в «речі», але в різних структурах буття виявляються різні ранги Істини Віри, Сутності, Факту, Процесу, Тенденції, Краси, Добра, Зла тощо.

У створенні людської реальності наявний об'єктивно-речовий світ але вчені стверджують про існування «афектації» надлюдського світопорядку, в якому виявлено імпульс Буття. Всі апріорні форми суб'єктної «гештальтреальності», феноменологічні, прагматичні, нормативно-ціннісні, концептуальні, знаково-символічні та інші форми «ейдосів», як результат втручання духу в стихію буття, своєю основою мають реальність.

Об'єктивна реальність як універсум плюралістичних сутностей, суб'єкт-об'єктних взаємин позначається «збоченнями» еволюції. Ця доісторична «гіперреальність» на всіх фундаментальних рівнях «зустрічей» з суб'єктом, означених Пірсом як: «первинний», дух, що вільно грає 3 дійсністю; «вторинний», рівень існування речей як низка індивідуальних об'єктів, що чинять опір конструктивній свободі духу і обмежують останній, і «третинний», коли утворюється рівень справжньої реальності», світ універсалій. Вони виступають джерелом «онтологічної довіри» для суб'єкта, чиє «буття-у-світі», за Гайдеггером «розімкнуте на світ». У цьому сенсі «онтологічна цілісність» екзистенціалу, зв'язок фізичної природи й історії $є$ вихідною основою та онтологічною умовою гуманізму $[13,52]$.

В умовах глобалізації постмодерністську деконструювання онтологічної загальності та трансцендентності в мультипросторах 
особистості поступово втрачає «вектор» сутнісного та об'єктного мислення», занурюючись у філософію суб'єктивності за умови протистояння раціоналізму та ірраціоналізму.

Сьогодні теорія людської самості намагається залучити самопояснення як спосіб дійсності, де природа і предмети володіють природним правом, відповідно до ідей арістотелевсько-томістської традиції. Ця концепція закликає до свободи та субстанціювання соціального життя.

Розумінню сущого відповідає концепція «індивід-монада Лейбніца», «ставлення» $\mathrm{i}$ «функції» постмодерне мислення протиставляє есенціальний і ентелехіальний образ, зафіксований у часі та просторі однократності» [4, 47]. Отже, інтелектуально-духовним, світоглядним, науковим, політичним ціннісним пошукам XX століття, постмодернізм намагається «протиставити» нову епісистему граничних підвалин орієнтації «егоїстичних» онтологій, «обстоює» свободу для людини 3 володіння іншим, пригніченням іншого, експлуатацією реальності» $[6,63]$.

Утвердження істини буття як володіння іншим (що заперечує незалежність іншого) створює філософію могутності, тиранію держави, філософію влади. I в цьому безособовому універсалізмі, стверджує Левінас, простежується ще одна грань нелюдськості.

У М.Фуко дискурсивне «скам'яніння», об'єктивацію людських життєвих практик, їх просторово-тимчасове відчуження перетворює на знак речовинно-об'єктних просторів, які є нормативно-дисциплінарними, владними джерелами соціально-об'єктного придушення індивіда. 3 буттям М.Фуко пов'язує не тотальність людського (значущість речей і всього того, що спонукує його до існування), а пріоритет існуючого над буттям, що означає подальший вихід 3 підпорядкування класичній філософії $[12,149]$. Наявність різних рівнів, порядків і способів людського буття дозволяє Фуко стверджувати про небезпеку «розпилення» і зникнення людини, якщо ми не зможемо залишити той епістемічний простір рефлексії, який грунтується на кантівській критиці філософських завдань.

Х.Янарас описує сучасне глобалізоване суспільство як «торжество історичного матеріалізму в його капіталістичній формі» $[14,81]$. На його думку, глобалізація є поширенням історичного матеріалізму капіталістичного суспільства, абсолютизованого споживацтва під виглядом завоювання світу ідеями лібералізму. Оскільки реальна владу в суспільстві сучасного капіталізму сконцентровано в руках 
транснаціональних корпорацій, то, відповідно, свобода вибору є позірністю без змісту. Янарас доводить, що суспільство глобалізованого капіталізму робить людину рабом споживацтва, обмежуючи свободу. Людина погоджується пожертвувати власною свободою за примарний життєвий успіх у сьогоденні. $Є$ лише єдина проблема: неможливість подолати смерть.

М.Вебер, Т.Парсонс у концепції соціальних змін та еволюції звернулися до поняття еволюції соціальних систем, яке дозволяє фіксувати зміни та трансформації сучасного суспільства, культури, моралі тощо. Збільшення інформації спричинює виникнення масиву неправдивої інформації, поширення екстремістських та інших негативних ідей.

Р.Арон, У.Ростоу, Дж.Гелбрейт, Д.Белл у своїх працях наголошують на значущості засобів, покликаних забезпечити матеріальну й моральну «стабільність», «безконфліктність», «стійкість», «реалізацію творчих можливостей». Вони допоможуть подолати Зло в суспільному житті, бо технічні показники - це показники прогресу. Важливим аспектом техногенної культури $\epsilon$ ідеї підкорення людиною природи і перетворення світу, який породжував особливе ставлення до ідей панування сили і влади. У глобалізованому світі процес здійснення панування є безпосереднім примусом влади однією людиною над іншою. Тому актуалізуються ідеї війн, агресії, ідей сили, яку варто застосовувати для підкорення цілих народів.

Сучасні вчені наголошують на тому, що метою існування зла, $€$ інформаційне підкорення людства. У індивідів розвинуто культурі споживання, яку спрямовують на самозадоволення повсякденних потреб та інстинктів, а це зумовлює трансформацію системи цінностей життя, яка грунтується на безпринципності, індивідуалізмі, прагматизмі.

У XX-XXI ст. сформувалося суспільство споживання. У ньому споживання, перетворюючись на соціальний інститут, сприймається як спосіб колективної поведінки і набуває статусу найвищої соціальної і моральної цінності принципу громадського устрою.

Постмодернізм намагається створити нові онтології свободи для людини з володіння іншим, пригніченням іншого, експлуатацією реальності. Утвердження істини буття як володіння іншим створює філософію могутності, тиранії держави, філософію влади. I в цьому полягає безособовий універсалізм. У підсумку розвинуте суспільство споживання змінює відношення між раціональним та ірраціональним, викликаючи існування кількох реальностей. 
Перспективи подальших наукових досліджень пов'язані з розкриттям сутності зла в умовах глобалізації, інформатизації та суспільства споживання, з руйнуванням культури і моралі як виявом зла.

\section{ЛITЕРАТУРА}

1. Блаватская Е. Тайная Доктрина. - Т.2. - М., 2010. - 944 с.

2. Блох Э. Тюбингенское введение в философию. - Екатеринбург, 1997. - C. 192.

3. Василий. Собрание трудов / архим. Василий (Пронин). - Ужтород, 2010. Т. 1 : Жизнеописание ; Научные и богословские исследования. -432 c.

4. Козловский П. Культура постмодерна. - М., 1997. - С.47.

5. Кондорсе М.Ж. Эскиз исторической картины прогресса человеческого разума. - М., 1936. - С. 8.

6. Левинас Э. Тотальность и бесконечное: все о внешности // Вопросы философии. - 1999. - № 2. - С. 63.

7. Лейбнии Г.В. Труды по философии науки. - М., 2010. - 178 с. - (Из наследия мировой философской мысли. Философия науки).

8. Лосский Н.О. Ценность и бытие : Бог и Царство Божие как основа ценностей. - Харьков; Москва, 2000. - 864 с. - (Библиотека «Р. Х. 2000». Серия «Религиозная философия»).

9. Роулз Дж. Теория справедливости. - Новосибирск, 1995. - 536 с.

10. Тейлор Ч. Джерела себе; [пер. з англ. під редакцією Андрія Васильченка]. - К., 2005. - 696 с.

11. Уханов Е.В. Эссе об одиночестве, или тоска Я по Другому в сетевых коммуникациях [Електронний ресурс]. - Режим доступу :

http://philosophystorm.org/files/my_.html.

12. Фуко М. Слова и вещи. - СПб., 1994. - С. 149.

13. Хайдегzер М. Бытие и время. - М., 1997. - С.52-64.

14. Яннарас X. Церковь в посткоммунистической Европе // Церковь и время : Научно-богословский и церковно-общественный журнал. 2004. - №3 (28). - C. 81-106.

15. Marcuse H. Eros and Civilization. - Boston, 1955. - P. 96.

Несправа М.В. За межами розуміння зла у філософії постмодерну.

У статті досліджуються складники світогляду нової техно-інформаційної цивілізації. Розширено зміст розуміння зла в умовах інформаційної цивілізації, нове розуміння його сутності. Описано особливості життєдіяльності 
індивіда, існування зла і добра, висвітлено роль суспільства споживання інформації в суспільному розвитку.

Здійснено аналіз визначення меж зла та їх актуалізації. Дано тлумачення категорії зла у філософії постмодерну. Актуальність дослідження зла зумовлена новими реаліями інформаційної цивілізації. Звернення філософів до категорії зла, спричинене кризою культури та духовності, постає як заперечення повноти буття, утвердженням хаосу, множинності та егоїзму. Визначено концепції, у яких описано поступ цивілізації як процес деградації культури, як поступову деградацію добра. Показано об'єктивність добра, його божественну сутність. Розглянуто питання, що стосуються природи зла, сутності та змісту негативних моральних цінностей.

Ключові слова: буття, цивілізація, людина, інформатизація, глобалізація, суспільство споживання, добро, зло.

Несправа М.В. За пределами понимания зла в философии постмодерна.

В статье исследуются составляющие мировоззрения новой техноинформационной цивилизации. Расширен смысл понимания зла в условиях информационной цивилизации, новое понимание его сущности. Описаны особенности жизнедеятельности индивида, существование зла и добра, освящена роль общества потребления информации в общественном развитии.

Проанализированы определения граней зла и их актуализации. Дано истолкование категории зла в философии постмодерна. Актуальность исследования зла обусловлена новыми реалиями информационной цивилизации. Обращение философов к категории зла связано с кризисом культуры и духовности, предстает как отрицание полноты бытия, как утверждение хаоса, множественности и эгоизма. Определены концепции, в которых описано поступательное движение цивилизации как процесс деградации культуры, как постепенную деградацию добра.

Показаны объективность добра и его божественная сущность. Рассмотрены вопросы, касающиеся природы зла, сущности и содержания негативных моральных ценностей.

Ключевые слова: бытие, цивилизация, человек, информатизация, глобализация, общество потребления, добро, зло.

Nesprova M.V. Beyond comprehension of evil in postmodern philosophy.

The article examines the ideology components of the new technological and information civilization, an expanded sense of evil understanding in terms of information civilization, new understanding of the essence. Peculiarities of the individual's activity, the existence of good and evil, roles of society's information consumption of informatization in social development are described.

The article is devoted to definition of edge of evil and mainstreaming. Understanding of the category of evil in postmodern philosophy, as a process 
of development of civilizations and ways of development of mankind. The relevance of the study of evil due to its modernization in connection with the new realities of the information civilization. The appeal to the category of evil asso-ciated with the crisis of culture and spirituality, appears as a denial of the fullness of being, an affirmation of chaos, multiplicity and selfishness. The article examines the influence of philosophical ideas of Leibniz, A.Maktari process of the formation of postmodern philosophy. Concepts by K. Marx, N.I.Danilevsky, O.Spengler, A.Toynbee, K.Jaspers described the civilization progress as the process of degradation of culture, as gradual degradation of good.

The existence of modern people - this being in multiple dimensions, multirealities associated with life in illusions. Thus the ideas of G. Snooks, A.Panov, N.Moiseyev, A. Nazaretyan, S. Huntington, and others seem to be interesting. Technology intellectualization, humanization also hide certain dangers to humans, to transformation of its will. The processes of development of civilizations and human development are described by philosophers Fukuyama F., Wallersteiner V., Huntington S., P.J. Buchanan etc. Importance of virtual reality for the present and attitude mark A.Alekseyev, A.Boiko, F.Vlasenko, N.Milanova, S.Kurbatov, S.Marika, A.Perelomov and other. It is emphasized that today perception of space and time are disturbed. Issues concerning the nature of evil, the nature and content of the negative moral values are studied. The phenomenon of objectivity, the nature of goodness, and its divine nature. The specific features of the evil conceptualization as the world of information of human existence are revealed. The emergence of a new type of society - a society of consumption is determined.

The concepts describing the civilization progress as the process of degradation of culture, as gradual degradation of good are defined. The objectivity of the nature of goodness, and its divine nature. Issues concerning the nature of evil, the nature and content of the negative moral values are studied.

Key words: entity, civilization, individual, informatization, globalization, consumer society, good, evil. 